\title{
Dual-Band Plasmonic Perfect Absorber Based on the Hybrid Halide Perovskite in the Communication Regime
}

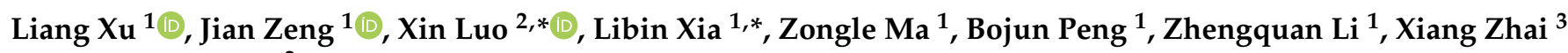 \\ and Lingling Wang ${ }^{3}$ \\ 1 Energy Materials Computing Center, School of Energy and Mechanical Engineering, Jiangxi University of \\ Science and Technology, Nanchang 330013, China; liangxu@hnu.edu.cn (L.X.); \\ 6720190967@mail.jxust.edu.cn (J.Z.); 6120190960@mail.jxust.edu.cn (Z.M.); \\ 6720180481@mail.jxust.edu.cn (B.P.); zhengquan.li@jxust.edu.cn (Z.L.) \\ 2 School of Science, East China Jiaotong University, Nanchang 330013, China \\ 3 Key Laboratory for Micro-Nano Optoelectronic Devices of Ministry of Education, School of Physics and \\ Electronics, Hunan University, Changsha 410082, China; kele1110@hnu.edu.cn (X.Z.); \\ llwang@hnu.edu.cn (L.W.) \\ * Correspondence: remeo@hnu.edu.cn (X.L.); franson@jxust.edu.cn (L.X.)
}

Citation: Xu, L.; Zeng, J.; Luo, X.; Xia, L.; Ma, Z.; Peng, B.; Li, Z.; Zhai, X.;

Wang, L. Dual-Band Plasmonic Perfect Absorber Based on the Hybrid Halide Perovskite in the Communication Regime. Coatings 2021, 11, 67. https://doi.org/10.3390/coatings 11010067

Received: 13 November 2020 Accepted: 29 December 2020 Published: 8 January 2021

Publisher's Note: MDPI stays neutral with regard to jurisdictional clai$\mathrm{ms}$ in published maps and institutional affiliations.

Copyright: (C) 2021 by the authors. Licensee MDPI, Basel, Switzerland. This article is an open access article distributed under the terms and conditions of the Creative Commons Attribution (CC BY) license (https:// creativecommons.org/licenses/by/ $4.0 /)$.

\begin{abstract}
Due to the weak absorption of $\left(\mathrm{CH}_{3} \mathrm{NH}_{3}\right) \mathrm{PbI}_{3}$ in the communication regime, which restricts its optoelectronic applications, we design a adjustable dual-band perfect absorber based on the $\left(\mathrm{CH}_{3} \mathrm{NH}_{3}\right) \mathrm{PbI}_{3}$ to significantly enhance its absorption capability. Since the localized plasmon (LP) mode and surface plasmon (SP) mode are excited in the structure, which can both greatly enhance light absorption of the $\left(\mathrm{CH}_{3} \mathrm{NH}_{3}\right) \mathrm{PbI}_{3}$ layer, dual-band perfect absorption peaks are formed in the communication regime, and the absorption of $\left(\mathrm{CH}_{3} \mathrm{NH}_{3}\right) \mathrm{PbI}_{3}$ layer is increased to $43.1 \%$ and $64.2 \%$ at the dual-band absorption peaks by using finite-difference time-domain (FDTD) methods, respectively. By varying some key structural parameters, the dual-band absorption peaks of $\left(\mathrm{CH}_{3} \mathrm{NH}_{3}\right) \mathrm{PbI}_{3}$ can be separately shifted in a wide wavelength region. Moreover, the designed absorber can keep good performance under wide angles of incidence and manifested polarization correlation. Furthermore, not just for $\left(\mathrm{CH}_{3} \mathrm{NH}_{3}\right) \mathrm{PbI}_{3}$, the physical mechanism in this absorber can also be utilized to strengthen the absorption of other halide perovskites.
\end{abstract}

Keywords: plasmonics; absorption; metamaterial; halide perovskites

\section{Introduction}

Nowadays, efficient light matter interaction is greatly conductive to develop optoelectronics and nanophotonics [1-4]. Many new materials, including transition-metal dichalcogenides [5-7], graphene [8-10], hexagonal boron nitride [11,12], black phosphorus $[13,14]$ et al., have been widely reported for achieving the effective light matter interaction. Recently, the new halide perovskites materials described by the general formula $\mathrm{ABZ}_{3}\left(\mathrm{~A}=\right.$ organic ammonium cation, $\left.\mathrm{Cs}^{+} ; \mathrm{B}=\mathrm{Pb}^{2+}, \mathrm{Sn}^{2+} ; \mathrm{Z}=\mathrm{Cl}, \mathrm{Br}, \mathrm{I}\right)$, have caused wide public concern for both photon sources [15-17] and photovoltaics devices [18,19], due to the unique photoelectric characteristics, including outstanding visible light response, strong photoluminescence, long carrier diffusion length, ultra-broadband spectral tunability, and so on [20-22]. In fact, the halide perovskites have been found for more than 30 years. Until 2009, A. Kojima et al. [23] proved that a solar cell based on $\left(\mathrm{CH}_{3} \mathrm{NH}_{3}\right) \mathrm{PbI}_{3}$ can realize the power conversion efficiency (PCE) as 3.8\%, which made the halide perovskites more and more popular in photovoltaic devices as a new generation of semiconductor material.

Recent years, halide perovskites have been made great progress in the solar field. By using $\left(\mathrm{CH}_{3} \mathrm{NH}_{3}\right) \mathrm{PbI}_{3}$ nanoparticles as light harvesters in the solar cells, M. Gratzel et al. enhanced the PCE to 9.7\% [24] in 2012. One year later, A. Hey et al. [25] increased the PCE to $12.3 \%$ by adjusting the processing temperature of $\left(\mathrm{CH}_{3} \mathrm{NH}_{3}\right) \mathrm{PbI}_{3-\mathrm{x}} \mathrm{Cl}_{\mathrm{x}}$ solar cells 
from $500{ }^{\circ} \mathrm{C}$ to below $150{ }^{\circ} \mathrm{C}$. Further researches showed that changing the components of the halide perovskite and seriously selecting the other materials are very useful to increase PCE. For instance, without antireflective coating, PCE can be as high as $19.3 \%$ in a plane structure [26]. Until now, the PCE of halide perovskite solar cell has been reached $23 \%$, and even with the potential exceeds $30 \%[27,28]$. More importantly, the efficiency is already better than multi-crystalline silico-based solar cells (22.3\%), which demonstrates great potential of halide perovskite solar cell in photovoltaic applications. Moreover, it is worth noting that the large optical absorption coefficient of halide perovskites in the visible regime takes an important part in these halide perovskite-based solar cells. However, the weak absorption coefficient limits the further applications of halide perovskites in the communication regime. Actually, halide perovskites are very instructive to research on photoelectric devices with excellent performance in the communication regime, although the related reports are still relatively rare. In this paper, we use the unique properties of metal metamaterials $[29,30]$ to enhance the optical absorption of $\left(\mathrm{CH}_{3} \mathrm{NH}_{3}\right) \mathrm{PbI}_{3}$ in the near-infrared regime. Then, we design and investigate a $\left(\mathrm{CH}_{3} \mathrm{NH}_{3}\right) \mathrm{PbI}_{3}$-based optical absorber combined with metal metamaterial in the communication regime.

\section{Structure Design}

As seen from Figure 1, the designed absorber is composed of periodic silver (Ag) strips on the $\mathrm{SiO}_{2}$ layer, which is coated with $\left(\mathrm{CH}_{3} \mathrm{NH}_{3}\right) \mathrm{PbI}_{3}$ layer supported by the $\mathrm{Ag}$ substrate, and the $\left(\mathrm{CH}_{3} \mathrm{NH}_{3}\right) \mathrm{PbI}_{3}$ layer is sandwiched by two anisotropic lossless hexagonal boron nitride (h-BN) films. Compared with only utilizing a $\mathrm{SiO}_{2}$ layer, the h-BN films and $\left(\mathrm{CH}_{3} \mathrm{NH}_{3}\right) \mathrm{PbI}_{3}$ layer together constitute the heterojunction to maintain higher carrier mobility in structure. The thickness of $\mathrm{SiO}_{2}$ layer is $D_{1}=230 \mathrm{~nm}$, the thickness of $\mathrm{Ag}$ substrate is $D_{2}=800 \mathrm{~nm}$, and the thickness ( $z$ direction) of each h-BN film is $10 \mathrm{~nm}$. Since the thickness of the Ag substrate is too thick to let the incident light penetrate through it, the transmission in the whole structure is near zero, that is $T=0$. In this condition, the absorption of this structure can be expressed by $A=1-R(R$ is the reflection from the whole structure). Simultaneously, the widths (in the $x$ direction) and thicknesses of the Ag strips are expressed by $w$ and $h$, respectively. Meanwhile $P$ is the period of the Ag strips in the $x$ direction. Then, the filling factor of the Ag strips is described by $F=w / p$. In calculation, $w=550 \mathrm{~nm}, P=800 \mathrm{~nm}, h=15 \mathrm{~nm}$, and the $\left(\mathrm{CH}_{3} \mathrm{NH}_{3}\right) \mathrm{PbI}_{3}$ layer is employed with thickness of $100 \mathrm{~nm}$ in this structure. The permittivity of Ag is calculated by the Drude formula [31], and the optical parameters of h-BN films in our simulation are obtained from the paper [32]. Moreover, the absorption of $\left(\mathrm{CH}_{3} \mathrm{NH}_{3}\right) \mathrm{PbI}_{3}$ is described by the equation [33]:

$$
A(l)=\frac{4 p c}{l} g \operatorname{Re}(N) g \operatorname{Im}(N) g \int_{V}\left|E_{l}\right|^{2} d V
$$

where $N$ is the refractive index of $\left(\mathrm{CH}_{3} \mathrm{NH}_{3}\right) \mathrm{PbI}_{3}, \lambda$ is the wavelength of incident light, $c$ is velocity of light in vacuum, $V$ is the volume of $\left(\mathrm{CH}_{3} \mathrm{NH}_{3}\right) \mathrm{PbI}_{3}$, and $E_{l}$ is the local electric field. Then, dual-band perfect absorption peaks are formed in the communication regime through the use of finite-difference time-domain (FDTD) methods, and the absorption of $\left(\mathrm{CH}_{3} \mathrm{NH}_{3}\right) \mathrm{PbI}_{3}$ is increased to $43.1 \%$ and $64.2 \%$ at the dual-band absorption peaks, respectively. Meanwhile, by varying some key structural parameters, the dual-band absorption peaks of $\left(\mathrm{CH}_{3} \mathrm{NH}_{3}\right) \mathrm{PbI}_{3}$ can be separately shifted in a wide wavelength region. Moreover, the designed absorber can keep good performance under wide angles of incidence and manifested polarization correlation. 


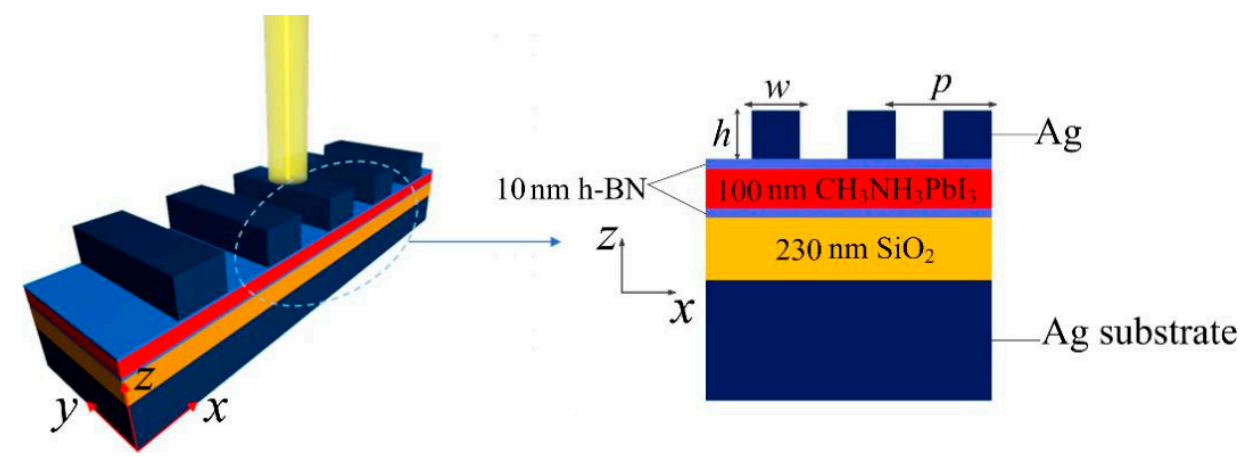

Figure 1. Structural figure of the dual-band $\left(\mathrm{CH}_{3} \mathrm{NH}_{3}\right) \mathrm{PbI}_{3}$-based perfect absorber.

And we used the first-principles to calculate the dielectric function $\left(\varepsilon=\varepsilon_{1}-i \varepsilon_{2}\right)$ of $\left(\mathrm{CH}_{3} \mathrm{NH}_{3}\right) \mathrm{PbI}_{3}$ in software VASP [34,35]. The electron exchange-correlation function is adopted by the generalized gradient approximation (GGA) in the Perdew Burke-Ernzerhof (PBE) method [36]. In the calculation, the first Brillouin zone is performed with the Monkhorst-Pack k-points grid of $15 \times 15 \times 15$, and the basis set energy cutoff of plane-wave is set as $500 \mathrm{eV}$. The convergence criterion of energy and force are assumed as $1 \times 10^{-8} \mathrm{eV}$ and $1 \times 10^{-8} \mathrm{eV} / \AA$, respectively. Meanwhile, the usual Kramers-Kronig transformation is used to obtain the real part $\varepsilon_{1}$ of the dielectric function, while the imaginary part $\varepsilon_{2}$ is solved from the summation over empty states. The calculation results of the dielectric function are shown in Figure 2, which are almost consistent with the previously reported results [37]. Clearly, the value of imaginary part $\left(\varepsilon_{2}\right)$ in the visible band is high, which demonstrates the $\left(\mathrm{CH}_{3} \mathrm{NH}_{3}\right) \mathrm{PbI}_{3}$ is a good material in photovoltaic field. However, its further application in the optical communication is limited by the low value of $\varepsilon_{2}$ in the communication band. Therefore, it is of great significance to study and improve the absorption of $\left(\mathrm{CH}_{3} \mathrm{NH}_{3}\right) \mathrm{PbI}_{3}$ in the communication regime.

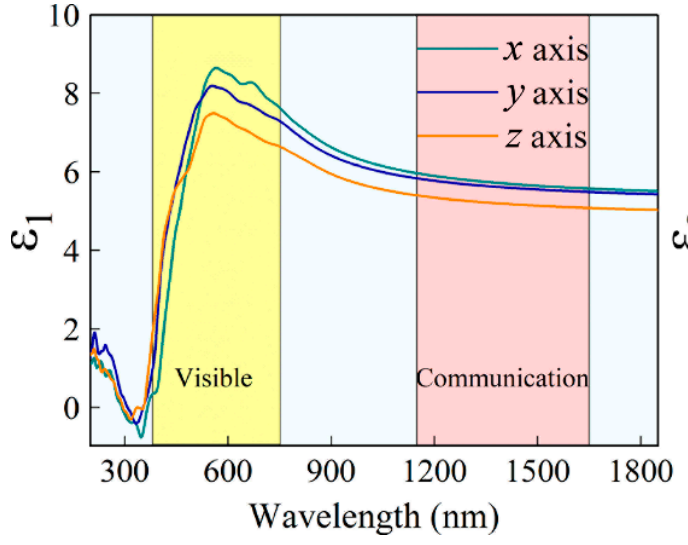

(a)

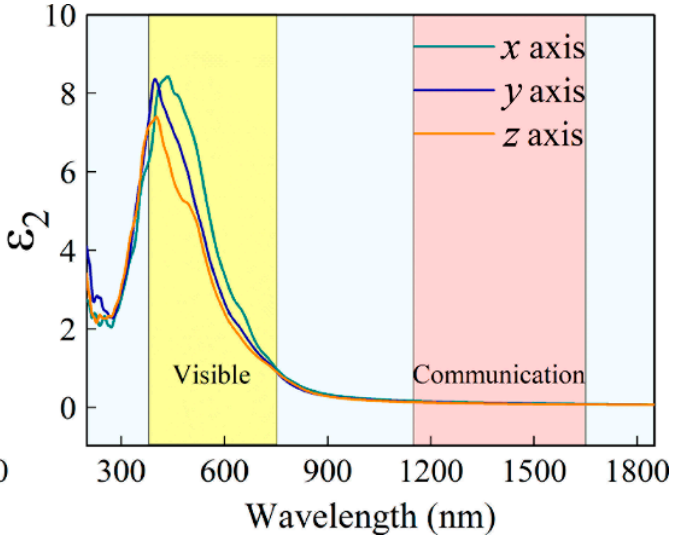

(b)

Figure 2. (a) Real part $\varepsilon_{1}$ and (b) imaginary part $\varepsilon_{2}$ of dielectric function of $\left(\mathrm{CH}_{3} \mathrm{NH}_{3}\right) \mathrm{PbI}_{3}$ based on the first-principles calculation.

\section{Results and Discussion}

Firstly, under normal incidence condition, we consider the absorption of this absorber and $\left(\mathrm{CH}_{3} \mathrm{NH}_{3}\right) \mathrm{PbI}_{3}$ layer by shining from $p$-polarized and s-polarized light separately, as exhibited in Figure 3. When the structure is shined from s-polarized light, both the absorption of the absorber and $\left(\mathrm{CH}_{3} \mathrm{NH}_{3}\right) \mathrm{PbI}_{3}$ are rather weak in this condition. It is because plasmonic resonance is hardly excited when the electric field of s-polarized light is parallel to the Ag strips. On the other hand, when the structure is shined from $p$-polarized light, both the surface plasmonic resonance and localized plasmonic resonance can be 
excited in the proposed absorber. Meanwhile, the absorption of $\left(\mathrm{CH}_{3} \mathrm{NH}_{3}\right) \mathrm{PbI}_{3}$ has been obviously increased to $43.1 \%$ at $\lambda_{1}=1291 \mathrm{~nm}$ and $64.2 \%$ at $\lambda_{2}=1548 \mathrm{~nm}$, respectively. Thus, the performance of our proposed absorber is remarkably polarization-sensitive, s-polarized light is not conducive to increase absorption in $\left(\mathrm{CH}_{3} \mathrm{NH}_{3}\right) \mathrm{PbI}_{3}$. For this reason, the impacts of p-polarized light are our main concern on the next content.

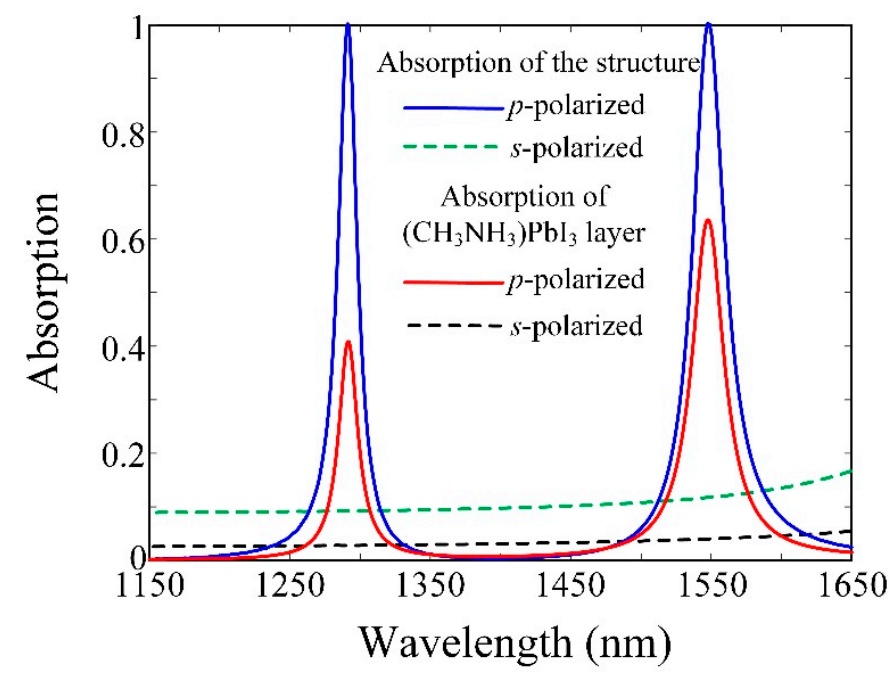

Figure 3. Absorption of the proposed structure and $\left(\mathrm{CH}_{3} \mathrm{NH}_{3}\right) \mathrm{PbI}_{3}$ layer under illumination of p-polarized and s-polarized normal incident light, respectively, where $P=800 \mathrm{~nm}, w=550 \mathrm{~nm}$, $h=15 \mathrm{~nm}$.

Next, we will go through how to realize the function of the dual-band perfect absorption for this structure. As seen from Figure 1, the whole structure can be approximately regarded as a periodic metal-insulator-metal (MIM) structure, which can suppress the reflection at the resonant wavelength. As mentioned before, the absorption of this structure can be expressed by $A=1-R$, that is, the absorption peak corresponds to the reflection dip when the reverse light fields are superimposed on each other in the absorber. Thus, we can explain the absorption enhancement for the $\left(\mathrm{CH}_{3} \mathrm{NH}_{3}\right) \mathrm{PbI}_{3}$ layer by analyzing the light field distributions. As depicted from Figure 4, at the peak wavelength of $\lambda_{1}=1291 \mathrm{~nm}$, the skin depth of $\mathrm{Ag}$ is $S_{1} \approx \frac{\lambda}{2 \pi I m(A g)} \approx 23.16 \mathrm{~nm}$, as the complex refractive index of $\mathrm{Ag}$ is $0.3534+8.876 i$. Simultaneously, at the absorption peak of $\lambda_{2}=1548 \mathrm{~nm}$, the skin depth of $\mathrm{Ag}$ is $S_{2} \approx \frac{\lambda}{2 \pi \operatorname{Im}(A g)} \approx 22.80 \mathrm{~nm}$, as the complex refractive index of sliver is $0.5378+10.81 i$. Consequently, the thicknesses of Ag strips are much less than both $S_{1}$ and $S_{2}$ leading to the interaction of optical fields at the interface of Ag strip/air separatrix and Ag strip/hBN interface. Thus, the electric fields surrounding the Ag strips are accumulated and strengthened, as described in Figure 4a,c. And the magnetic field is assembled between each Ag strip and substrate for the resonance mode at $\lambda_{1}$, although both of them are also gathered around the Ag strips, as described in Figure 4a,b. Actually, these characteristics refer to the excitation of localized plasmon (LP) mode. On the other hand, parallel electromagnetic field stripes extending the $\mathrm{z}$-axis are taken shape for the resonance mode at $\lambda_{2}$, as seen in Figure $4 \mathrm{~d}$. This means that the resonance mode at $\lambda_{2}$ as a surface plasmon (SP) mode accumulates the light energy surrounding the $\left(\mathrm{CH}_{3} \mathrm{NH}_{3}\right) \mathrm{PbI}_{3}$ layer and enhances the near field. Thus, both LP mode and SP mode can greatly enhance light absorption of the $\left(\mathrm{CH}_{3} \mathrm{NH}_{3}\right) \mathrm{PbI}_{3}$ layer. However, as seen in Figure 4e,f, at the wavelength of $\lambda_{3}=1400 \mathrm{~nm}$, which is away from resonance wavelength, light energies and optical fields are not concentrated and enhance the absorption of $\left(\mathrm{CH}_{3} \mathrm{NH}_{3}\right) \mathrm{PbI}_{3}$ layer. 


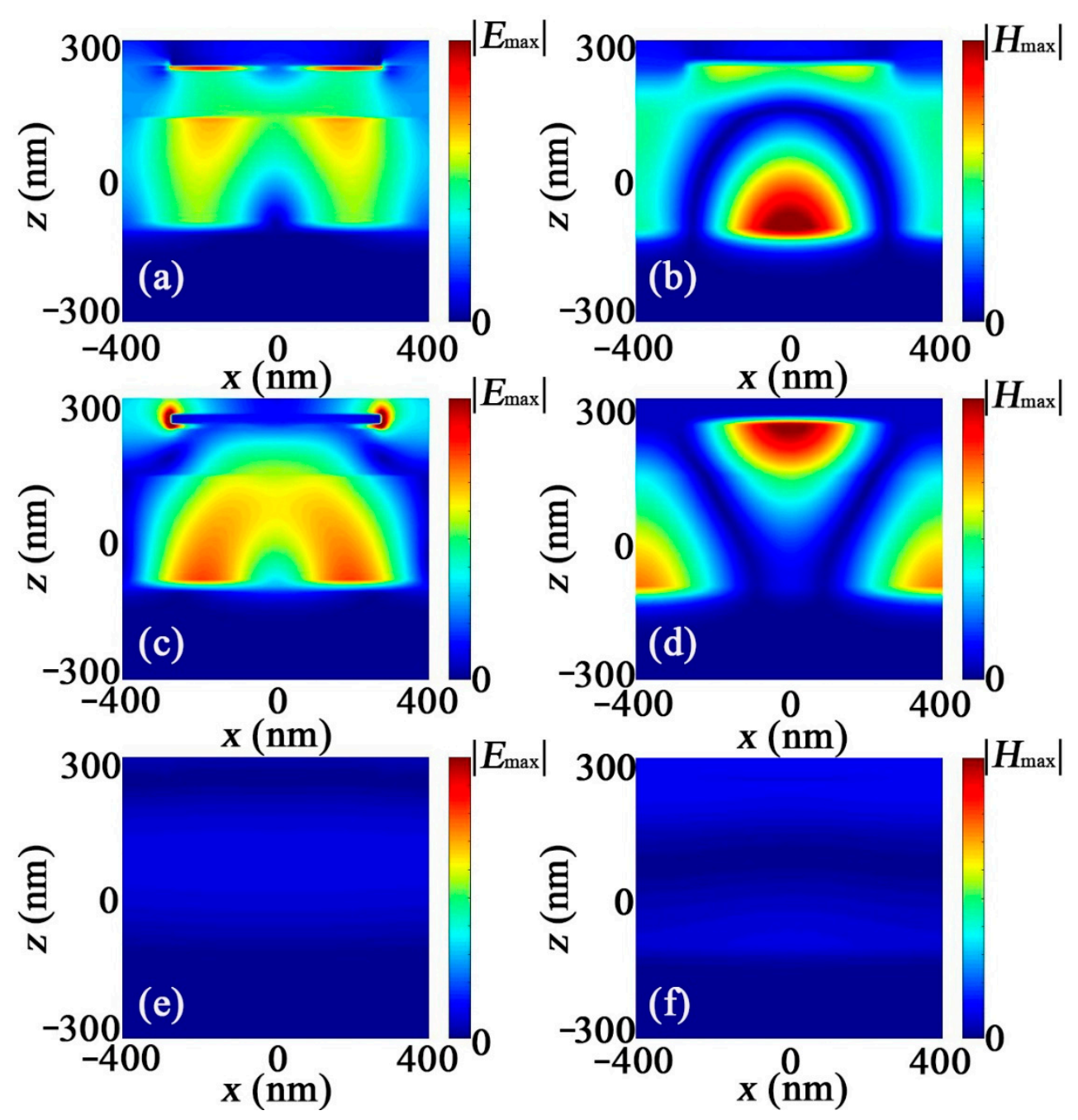

Figure 4. Contour profiles of normalized field of the structure under p-polarized incident light. (a) Electric and (b) magnetic fields at $\lambda_{1}=1291 \mathrm{~nm}$. (c) Electric and (d) magnetic fields at $\lambda_{2}=1548 \mathrm{~nm}$. (e) Electric and (f) magnetic fields at $\lambda_{3}=1400 \mathrm{~nm}$.

Subsequently, we study the effect of different widths of Ag strips on the absorption peaks of $\left(\mathrm{CH}_{3} \mathrm{NH}_{3}\right) \mathrm{PbI}_{3}$ layer, as shown in Figure 5a. Since every Ag strip exhibits as a Fabry-Perot (F-P) cavity for the LP mode, the wavelengths of absorption peaks are significantly correlated with the width of Ag strip. Therefore, when the width of Ag strip is increased, the absorption peak at $\lambda_{1}$ will be remarkably red-shifted owe to the gradually increasing effective wavelength of LP mode, which further leads to the enhancement and concentration of optical fields inside $\left(\mathrm{CH}_{3} \mathrm{NH}_{3}\right) \mathrm{PbI}_{3}$ layer and between adjacent $\mathrm{Ag}$ strips. Thus, the absorption will firstly increase with $w$. Unfortunately, if the width of Ag strip continues to be increased, too much Ag strips will cover the $\left(\mathrm{CH}_{3} \mathrm{NH}_{3}\right) \mathrm{PbI}_{3}$ layer. The absorption efficiency will stop increasing and turn into reduce. Meanwhile, since the wavelength of SP mode is not sensitive to $w$, when we change the width of Ag strip, the absorption peak at $\lambda_{2}$ has only a slight shift, which depends heavily on the period $P$ of $\mathrm{Ag}$ strips. As seen from Figure $5 c$, both the absorption peaks at $\lambda_{1}$ and $\lambda_{2}$ will be obviously red-shifted with the increase of $P$, due to the resonance wavelengths of LP and SP modes become longer and longer. By the same token, the absorption will firstly increase and then decline in whole process of increasing $P$. 

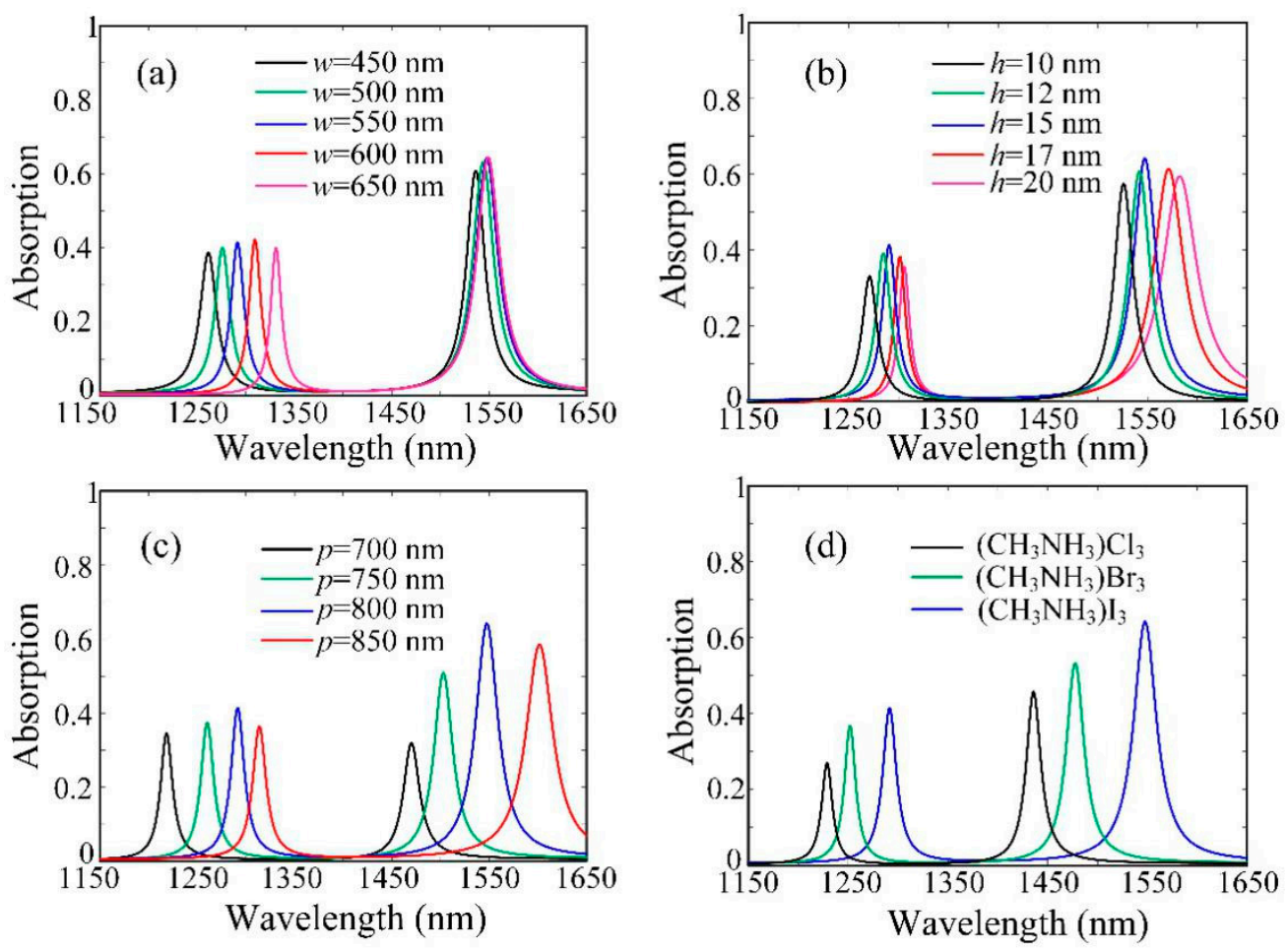

Figure 5. The absorption of $\left(\mathrm{CH}_{3} \mathrm{NH}_{3}\right) \mathrm{PbI}_{3}$ layer under normal incident $p$-polarized light with different (a) widths $w$, (b) thicknesses $h$, and (c) periods $P$ of silver strips, respectively. (d) Absorption spectra of different halide perovskites. The other parameters are the same as Figure 3.

In the following, what influences on the absorption of $\left(\mathrm{CH}_{3} \mathrm{NH}_{3}\right) \mathrm{PbI}_{3}$ layer caused by changing the thickness of Ag strips are considered, as shown in Figure $5 \mathrm{~b}$. When $h=15 \mathrm{~nm}$, which is much thinner than the depth of penetration, the optical fields inside the air $/ \mathrm{Ag}$ strip interface and h-BN/Ag strip interface are efficiently interacted with each other to improve the absorption of $\left(\mathrm{CH}_{3} \mathrm{NH}_{3}\right) \mathrm{PbI}_{3}$ layer, as mentioned above. When $h$ is increased from $15 \mathrm{~nm}$ to $20 \mathrm{~nm}$, the optical loss in the Ag strips is increased, and the coupling intensity between the top and bottom of Ag strips is weakened. As a result, both the absorption peaks of $\left(\mathrm{CH}_{3} \mathrm{NH}_{3}\right) \mathrm{PbI}_{3}$ layer at $\lambda_{1}$ and $\lambda_{2}$ are attenuated and blue-shifted slightly due to the reduction of resonance wavelength. However, much too thin Ag strips are not conducive to improve the absorption of $\left(\mathrm{CH}_{3} \mathrm{NH}_{3}\right) \mathrm{PbI}_{3}$ layer, owing to the reduction of optical fields around the $\left(\mathrm{CH}_{3} \mathrm{NH}_{3}\right) \mathrm{PbI}_{3}$ layer, and the strong light diffraction around the $\mathrm{Ag}$ strips. Consequently, when $h$ is reduced from $15 \mathrm{~nm}$ to $10 \mathrm{~nm}$, the absorption of $\left(\mathrm{CH}_{3} \mathrm{NH}_{3}\right) \mathrm{PbI}_{3}$ layer is obviously reduced. Furthermore, not just for $\left(\mathrm{CH}_{3} \mathrm{NH}_{3}\right) \mathrm{PbI}_{3}$, the physical mechanism in this absorber can also be utilized to strengthen the absorption of other halide perovskites, such as $\left(\mathrm{CH}_{3} \mathrm{NH}_{3}\right) \mathrm{PbBr}_{3}$, and $\left(\mathrm{CH}_{3} \mathrm{NH}_{3}\right) \mathrm{PbCl}_{3}$. As shown in Figure $5 \mathrm{~d}$, when the $\left(\mathrm{CH}_{3} \mathrm{NH}_{3}\right) \mathrm{PbI}_{3}$ layer in this absorber is changed by $\left(\mathrm{CH}_{3} \mathrm{NH}_{3}\right) \mathrm{PbBr}_{3}$ and $\left(\mathrm{CH}_{3} \mathrm{NH}_{3}\right) \mathrm{PbCl}_{3}$ respectively, both the absorption peaks of $\left(\mathrm{CH}_{3} \mathrm{NH}_{3}\right) \mathrm{PbBr}_{3}$ and $\left(\mathrm{CH}_{3} \mathrm{NH}_{3}\right) \mathrm{PbCl}_{3}$ layer also appear in the communication regime. Although the absorption peaks of $\left(\mathrm{CH}_{3} \mathrm{NH}_{3}\right) \mathrm{PbBr}_{3}$ and $\left(\mathrm{CH}_{3} \mathrm{NH}_{3}\right) \mathrm{PbCl}_{3}$ are not high enough in this case, we believe they can be optimized by manipulating the other structure parameters. Therefore, this method can be considered as a general approach to enhance absorption of most halide perovskites. Meanwhile, we also consider the effects of changing the thicknesses of h-BN layers, as shown in Figure 6. When the thicknesses of h-BN layers are increased from $6 \mathrm{~nm}$ to $10 \mathrm{~nm}$, the intensities and wavelengths of LP and SP modes are also increased, which lead to the increase and red-shift of absorption peaks of $\left(\mathrm{CH}_{3} \mathrm{NH}_{3}\right) \mathrm{PbI}_{3}$ layer. However, much too thick h-BN layers will weaken the coupling of plasmonic near fields between each Ag strip and the continuous Ag substrate, which lead to the reduction of optical fields 
around the $\left(\mathrm{CH}_{3} \mathrm{NH}_{3}\right) \mathrm{PbI}_{3}$ layer. Thus, when the thicknesses of h-BN layers are increased from $10 \mathrm{~nm}$ to $14 \mathrm{~nm}$, the absorption peaks of $\left(\mathrm{CH}_{3} \mathrm{NH}_{3}\right) \mathrm{PbI}_{3}$ layer are decreased.

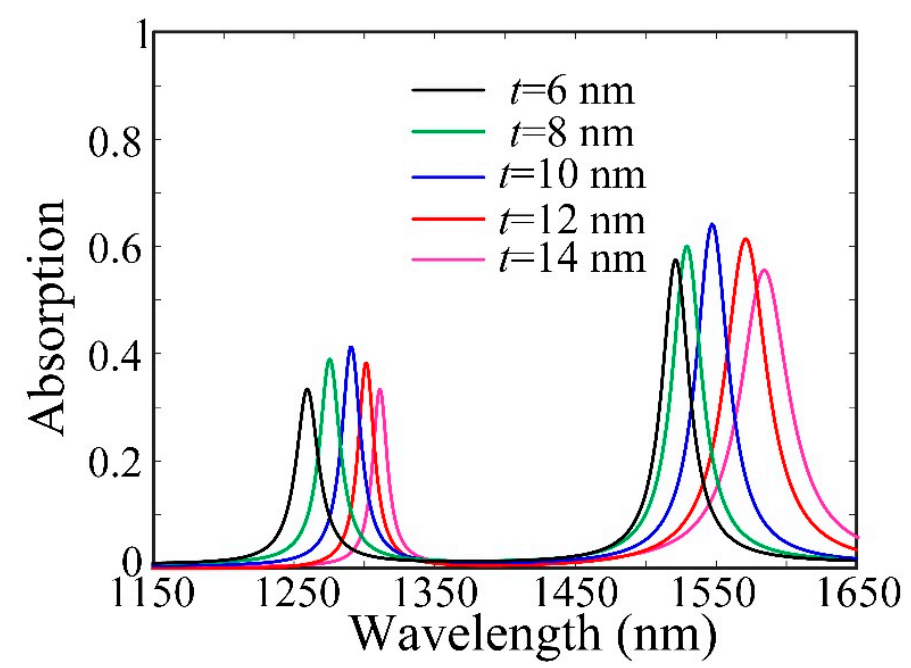

Figure 6. The absorption of $\left(\mathrm{CH}_{3} \mathrm{NH}_{3}\right) \mathrm{PbI}_{3}$ layer under normal incident $p$-polarized light with different thicknesses of h-BN layers.

In the next, it should be emphasized that all of results are obtained under the condition of normal incidence, however, the absorber in the application need keep good performance under wide angles of incidence. Then, we investigate the optical absorption of $\left(\mathrm{CH}_{3} \mathrm{NH}_{3}\right) \mathrm{PbI}_{3}$ as a function of angle and the wavelength of incident light. As shown in Figure 7 , the absorption of $\left(\mathrm{CH}_{3} \mathrm{NH}_{3}\right) \mathrm{PbI}_{3}$ at $\lambda_{1}$ and $\lambda_{2}$ are still more than $22 \%$ and $30 \%$, even if the angle of incident light is increased to $50^{\circ}$. Therefore, our designed absorber can keep good performance under wide angles of incidence in practical applications.

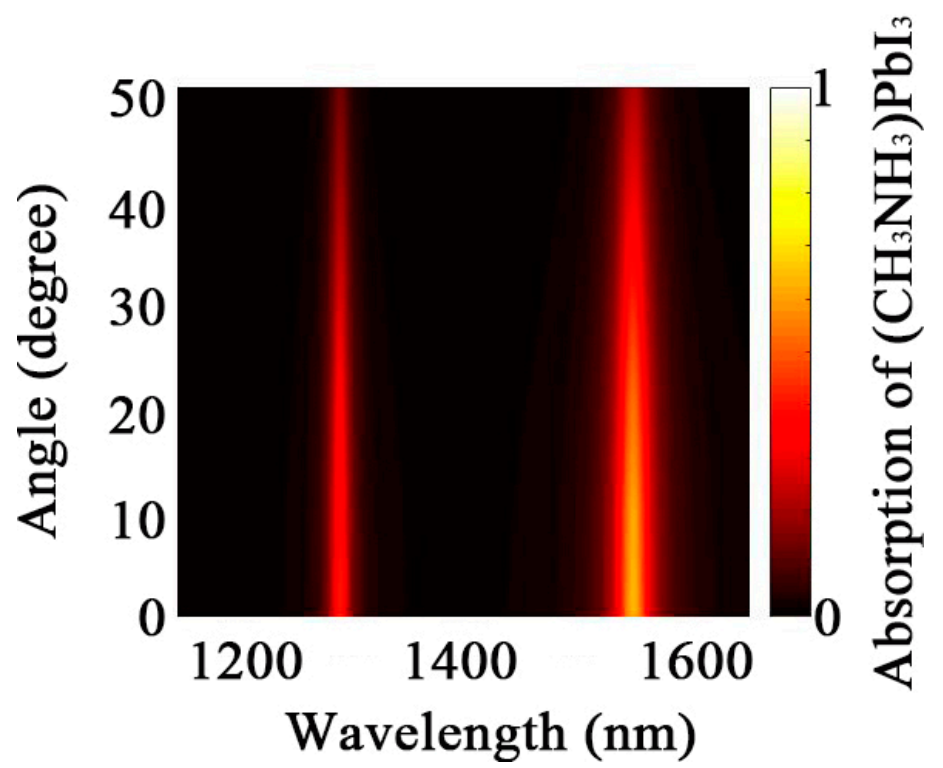

Figure 7. The absorption of $\left(\mathrm{CH}_{3} \mathrm{NH}_{3}\right) \mathrm{PbI}_{3}$ as a function of angle and the wavelength of $p$-polarized incident light.

\section{Conclusions}

In the summary, this paper designs a adjustable dual-band perfect absorber based on $\left(\mathrm{CH}_{3} \mathrm{NH}_{3}\right) \mathrm{PbI}_{3}$ in the communication regime, and the corresponding features are investigated through the use of FDTD methods. It is shown that the absorption of $\left(\mathrm{CH}_{3} \mathrm{NH}_{3}\right) \mathrm{PbI}_{3}$ 
layer is enhanced up to $43.1 \%$ and $64.2 \%$ at the dual-band absorption peaks in the communication regime, respectively. By varying some key structural parameters, the dual-band absorption peaks of $\left(\mathrm{CH}_{3} \mathrm{NH}_{3}\right) \mathrm{PbI}_{3}$ can be separately shifted in a wide wavelength region. Moreover, the designed absorber can keep good performance under wide angles of incidence and manifested polarization correlation. Furthermore, not just for $\left(\mathrm{CH}_{3} \mathrm{NH}_{3}\right) \mathrm{PbI}_{3}$, the physical mechanism in this absorber can also be utilized to strengthen the absorption of other halide perovskites. Thus, the proposed absorber has great application potential for dual-frequency and frequency selective photovoltaic devices in the communication regime.

Author Contributions: Conceptualization, L.X. (Liang Xu) and X.L.; methodology, L.X. (Liang Xu); software, X.L.; validation, J.Z., Z.M. and B.P.; formal analysis, L.X. (Libin Xia); investigation, L.X. (Liang Xu); resources, X.L.; data curation, X.Z.; writing-original draft preparation, L.X. (Libin Xia); writing-review and editing, X.L.; visualization, L.W.; supervision, Z.L.; project administration, Z.L.; funding acquisition, L.W. All authors have read and agreed to the published version of the manuscript.

Funding: This work was supported by the National Natural Science Foundation of China (Grant No. 11764018 and 61505052); Natural Science Foundation of Jiangxi Province (Grant No. 20192BAB212003, 20202ACBL211004); Science and Technology Project of the Education Department of Jiangxi Province (Grant No. GJJ180426 and GJJ200655).

Data Availability Statement: Data available in a publicly accessible repository.

Acknowledgments: This work was supported by the National Natural Science Foundation of China (Grant No. 11764018 and 61505052); Natural Science Foundation of Jiangxi Province (Grant No. 20192BAB212003, 20202ACBL211004); Science and Technology Project of the Education Department of Jiangxi Province (GJJ180426).

Conflicts of Interest: The authors declare no conflict of interest.

\section{References}

1. Geim, K.; Grigorieva, I.V. Van der Waals heterostructures. Nature 2013, 499, 419. [CrossRef] [PubMed]

2. Cheng, Z.Q.; Li, Z.L.; Luo, X.; Shi, H.Q.; Luo, C.L.; Liu, Z.M.; Nan, F. Enhanced second harmonic generation by double plasmon resonances in mesoscale flower-like silver particles. Appl. Phys. Lett. 2019, 114, 011901. [CrossRef]

3. Chen, K.; Adato, R.; Altug, H. Dual-band perfect absorber for multispectral plasmon-enhanced infrared spectroscopy. ACS Nano 2012, 6, 7998-8006. [CrossRef]

4. Wang, Y.Y.; Chen, Z.Q.; Xu, D.Y.; Yi, Z.; Chen, X.F.; Chen, J.; Tang, Y.J.; Wu, P.H.; Li, G.F.; Yi, Y.G. Triple-band perfect metamaterial absorber with good operating angle polarization tolerance based on split ring arrays. Results Phys. 2020, 16, 102951. [CrossRef]

5. Luo, X.; Liu, Z.M.; Cheng, Z.Q.; Liu, J.P.; Lin, Q.; Wang, L.L. Polarization-insensitive and wide-angle broadband absorption enhancement of molybdenum disulfide in the visible regime. Opt. Express 2018, 26, 33918. [CrossRef] [PubMed]

6. Xu, L.; Huang, W.Q.; Hu, W.Y.; Yang, K.; Zhou, B.X.; Pan, A.L.; Huang, G.F. Two-dimensional MoS 2 -graphene-based multilayer van der Waals heterostructures: Enhanced charge transfer and optical absorption, and electric-field tunable Dirac point and band Gap. Chem. Mater. 2017, 29, 5504. [CrossRef]

7. $\quad$ Li, J.K.; Chen, Z.Q.; Yang, H.; Yi, Z.; Chen, X.F.; Yao, W.T.; Duan, T.; Wu, P.H.; Li, G.F.; Yi, Y.G. Tunable broadband solar energy absorber based on monolayer transition metal dichalcogenides materials using au nanocubes. Nanomaterials 2020, $10,257$. [CrossRef] [PubMed]

8. Xia, S.X.; Zhai, X.; Wang, L.L.; Wen, S.C. Plasmonically induced transparency in in-plane isotropic and anisotropic 2D materials. Opt. Express 2020, 28, 7980. [CrossRef]

9. Luo, X.; Cheng, Z.Q.; Zhai, X.; Liu, Z.M.; Li, S.Q.; Liu, J.P.; Wang, L.L.; Lin, Q.; Zhou, Y.H. A tunable dual-band and polarizationinsensitive coherent perfect absorber based on double-layers graphene hybrid waveguide. Nanoscale Res. Lett. $2019,14,337$. [CrossRef]

10. Xiao, S.; Wang, T.; Liu, T.; Zhou, C.; Jiang, X.; Zhang, J. Active metamaterials and metadevices: A review. J. Phys. D Appl. Phys. 2020, 53, 503002. [CrossRef]

11. Xu, L.; Peng, B.J.; Luo, X.; Zhai, X.; Wang, L.L. A broadband and polarization-insensitive perfect absorber based on a van der Waals material in the mid-infrared regime. Results Phys. 2019, 15, 102687. [CrossRef]

12. Li, Q.; Xu, L.; Luo, K.W.; Li, X.F.; Huang, W.Q.; Wang, L.L.; Yu, Y.B. Electric-field-induced widely tunable direct and indirect band gaps in hBN/MoS2 van der Waals heterostructures. J. Mater. Chem. C 2017, 5, 4426. [CrossRef]

13. Lu, H.; Gong, Y.K.; Mao, D.; Gan, X.T.; Zhao, J.L. Strong plasmonic confinement and optical force in phosphorene pairs. Opt. Express 2017, 25, 5255. [CrossRef] [PubMed] 
14. Cai, Y.J.; Xu, K.D.; Feng, N.X.; Guo, R.R.; Lin, H.J.; Zhu, J.F. Anisotropic infrared plasmonic broadband absorber based on graphene-black phosphorus multilayers. Opt. Express 2019, 27, 3101. [CrossRef] [PubMed]

15. Sutherland, R.; Sargent, E.H. Perovskite photonic sources. Nat. Photonics 2016, 10, 295. [CrossRef]

16. Chen, S.T.; Roh, K.D.; Lee, J.H.; Chong, W.K.; Lu, Y.; Mathews, N.; Nurmikko, T.C.S.A. A photonic crystal laser from solution based organo-lead iodide perovskite thin films. ACS Nano 2016, 6, 3959. [CrossRef]

17. Zhou, H.; Dong, X.; Jiang, M.M.; Zheng, W.H.; Sun, L.X.; Zhao, B.B.; Tang, B.; Pan, A.L.; Zhang, L. Single-mode lasing and 3D confinement from perovskite micro-cubic cavity. J. Mater. Chem. C 2018, 6, 11740. [CrossRef]

18. Green, M.A.; Ho-Baillie, A.; Snaith, H.J. The emergence of perovskite solar cells. Nat. Photonics 2014, 8, 506. [CrossRef]

19. Makarov, S.; Furasova, A.; Tiguntseva, E.; Hemmetter, A.; Berestennikov, A.; Pushkarev, A.; Zakhidov, A.; Kivshar, Y. Halideperovskite resonant nanophotonics. Adv. Opt. Mater. 2019, 7, 1800784. [CrossRef]

20. Stranks, S.D.; Eperon, G.E.; Grancini, G.; Menelaou, C.; Alcocer, M.J.P.; Leijtens, T.; Herz, L.M.; Petrozza, A.; Snaith, H.J. Electron-hole diffusion lengths exceeding 1 micrometer in an organometal trihalide perovskite absorber. Science 2013, $342,341$. [CrossRef]

21. Dong, Q.; Fang, Y.; Shao, Y.; Mulligan, P.; Qiu, J.; Cao, L.; Huang, J. Solar cells. Electron-hole diffusion lengths $>175 \mu$ m in solution-grown CH3NH3PbI3 single crystals. Science 2015, 347, 967. [CrossRef] [PubMed]

22. Manser, J.S.; Christians, J.A.; Kamat, P.V. Intriguing optoelectronic properties of metal Halide Perovskites. Chem. Rev. 2016, 116, 12956. [CrossRef] [PubMed]

23. Kojima, A.; Teshima, K.; Shirai, Y.; Miyasaka, T. Organometal Halide Perovskites as visible-light sensitizers for photovoltaic cells. J. Am. Chem. Soc. 2009, 131, 6050. [CrossRef] [PubMed]

24. Kim, H.S.; Lee, C.R.; Im, J.H.; Lee, K.B.; Moehl, T.; Marchioro, A.; Moon, S.J.; Baker, R.H.; Yum, J.H.; Moser, J.E.; et al. Lead Iodide Perovskite sensitized all-solid-state submicron thin film mesoscopic solar cell with efficiency exceeding 9\%. Sci. Rep. 2012, 2, 591. [CrossRef] [PubMed]

25. Ball, J.M.; Lee, M.M.; Hey, A.; Snaith, H.J. Low-temperature processed meso-superstructured to thin-film perovskite solar cells. Energy Environ. Sci. 2013, 6, 1739. [CrossRef]

26. Zhou, H.; Chen, Q.; Li, G.; Li, G.; Luo, S.; Song, T.B.; Duan, H.S.; Hong, Z.R.; You, J.B.; Liu, Y.S.; et al. Interface engineering of highly efficient perovskite solar cells. Science 2014, 345, 542. [CrossRef]

27. Correa-Baena, J.P.; Abate, A.; Saliba, M.; Tress, W.; Jacobsson, T.J.; Gratzel, M.; Hagfeldt, A. The rapid evolution of highly efficient perovskite solar cells. Energy Environ. Sci. 2017, 10, 710. [CrossRef]

28. Zhang, Y.P.; Lim, C.K.; Dai, Z.; Yu, G.; Haus, J.W.; Zhang, H.; Prasad, P.N. Photonics and optoelectronics using nano-structured hybrid perovskite media and their optical cavities. Phy. Rep. 2019, 795, 1. [CrossRef]

29. Hao, J.; Zhou, L.; Qi, M. Nearly total absorption of light and heat generation by plasmonic metamaterials. Phys. Rev. B 2011, 83, 165107. [CrossRef]

30. Moreau, A.; Ciraci, C.; Mock, J.; Hill, R.; Wang, Q.; Wiley, B.; Chilkoti, A.; Smith, D.R. Controlled-reflectance surfaces with film-coupled colloidal nanoantennas. Nature 2012, 492, 86. [CrossRef]

31. Johnson, P.B.; Christy, R.W. Optical constants of the noble metals. Phys. Rev. B 1972, 6, 4370. [CrossRef]

32. Ishii, T.; Sato, T. Growth of single crystals of hexagonal boron nitride. J. Cryst. Growth 1983, 61, 689. [CrossRef]

33. Jackson, J.D. Classical Electrodynamics, 3rd ed; Wiley: Hobokennm, NJ, USA, 1999.

34. Kresse, G.; Hafner, J. Ab initio molecular dynamics for liquid metals. Phys. Rev. B 1993, 47, 558. [CrossRef] [PubMed]

35. Kresse, G.; Furthmuller, J. Efficient iterative schemes for ab initio total-energy calculations using a plane-wave basis set. Phys. Rev. $B$ 1996, 54, 11169. [CrossRef]

36. Grimme, S. Semiempirical GGA-type density functional constructed with a long-range dispersion correction. J. Comput. Chem. 2006, 27, 1787. [CrossRef]

37. Shirayama, M.; Kadowaki, H.; Miyadera, T.; Sugita, T.; Tamakoshi, M.; Kato, M.; Fujiseki, T.; Murata, D.; Hara, S.; Murakami, T.N.; et al. Optical transitions in hybrid perovskite solar cells: Ellipsometry, density functional theory, and quantum efficiency analyses for $\mathrm{CH}_{3} \mathrm{NH}_{3} \mathrm{PbI}_{3}$. Phys. Rev. A 2016, 5, 014012. [CrossRef] 